PROFESSING SELVES 



\section{PROFESSING SELVES}

TRANSSEXUALITY

AND SAME-SEX DESIRE IN

CONTEMPORARY IRAN

Afsaneh Najmabadi

Duke University Press Durham and London 2014 
(C) 2014 Duke University Press.

All rights reserved.

Printed in the United States of America on acid-free paper @.

Cover design by Amy Ruth Buchanan. Book interior design

by Courtney Leigh Baker. Typeset in Scala by Tseng Information

Systems, Inc.

Library of Congress Cataloging-in-Publication Data

Najmabadi, Afsaneh.

Professing selves : transsexuality and same-sex desire in

contemporary Iran / Afsaneh Najmabadi.

pages $\mathrm{cm}$

Includes bibliographical references and index.

ISBN 978-0-8223-5543-4 (cloth : alk. paper)

ISBN 978-o-8223-5557-1 (pbk. : alk. paper)

1. Transsexualism-Iran. 2. Sex change-Iran.

3. Gender identity-Iran. I. Title.

HQ77.95.I7N 352013

$306.76^{\prime} 80955-\mathrm{dc} 23$

2013025248 
FOR FARSHIDEH 